\title{
Thioredoxin-Interacting Protein
}

National Cancer Institute

\section{Source}

National Cancer Institute. Thioredoxin-Interacting Protein. NCI Thesaurus. Code

C113220.

Thioredoxin-interacting protein (391 aa, $44 \mathrm{kDa}$ ) is encoded by the human TXNIP gene.

This protein plays a role in the immune response and oxidative stress-stimulated signaling. 